\title{
EFFECTS OF ACTH AND CORTISONE ON THE ANAEMIA OF RHEUMATOID ARTHRITIS
}

\author{
BY \\ J. O. P. EDGCUMBE and O. A. N. HUSAIN \\ From the Group Laboratory, St. Mary Abbots Hospital, London
}

(RECEIVED FOR PUBLICATION SEPTEMBER 9, 1952)

The haematological effects of ACTH and cortisone on patients with rheumatoid arthritis have been described by Rosenthal and others (1950), Finch and others (1951), and Copeman and others (1952), but more information is needed.

\section{Material}

The present paper describes the haematological changes observed in a further twelve cases of rheumatoid arthritis during hormone therapy of 4 to 8 weeks' duration. All these patients had active polyarthritis of moderate severity associated with fever and increased sedimentation rates. Seven patients were treated with cortisone, the usual dose being $1,000 \mathrm{mg}$. the first week, $700 \mathrm{mg}$. the second week, and sufficient cortisone thereafter to maintain the clinical improvement of the first fortnight for a further 4 to 6 weeks. Five patients received ACTH in doses of between 45 and $760 \mathrm{mg}$. per week, sufficient being given to obtain and maintain clinical improvement (Table I). Analgesics, purgatives, etc., were allowed as needed and certain cases received iron preparations by mouth. Physiotherapy appropriate to their clinical condition was given. A thirteenth patient was investigated but did not receive hormone therapy.

\section{Methods of Investigation}

Before therapy -was started, the venous blood and sternal marrow of each patient were investigated by standard methods, mostly as described by Dacie (1950). Haemoglobin (oxyhaemoglobin) was estimated colorimetrically. Total eosinophil counts were made in a double Fuchs-Rosenthal chamber, using one volume of blood with nine volumes of the modification described by Henneman and others (1949) of Randolph's fluid (Randolph, 1944). The erythrocyte sedimentation rate (E.S.R.) was measured by the technique of Westergren (1921). The serum iron was estimated by the method of Tompsett and McAllister (1949). Marrow from the manubrium sterni was concentrated (as described by Dacie, 1950) before the films were spread on slides. 500 cells were counted for each myelogram; a further 1,500 cells were counted to determine the eosinophil percentages. Sections were made of small marrow fragments by a modification of the method of. White and others (1946).

After the start of therapy the blood counts and E.S.R.s were taken weekly. Marrow puncture was repeated once or twice during therapy at intervals which varied from 2 days to 5 weeks. The serum iron test was repeated in a few cases. Clinical improvement was assessed daily and, in greater detail, weekly.

TABLE I

DRUG AND WEEKLY DOSAGE (mg.) ADMINISTERED TO EACH PATIENT

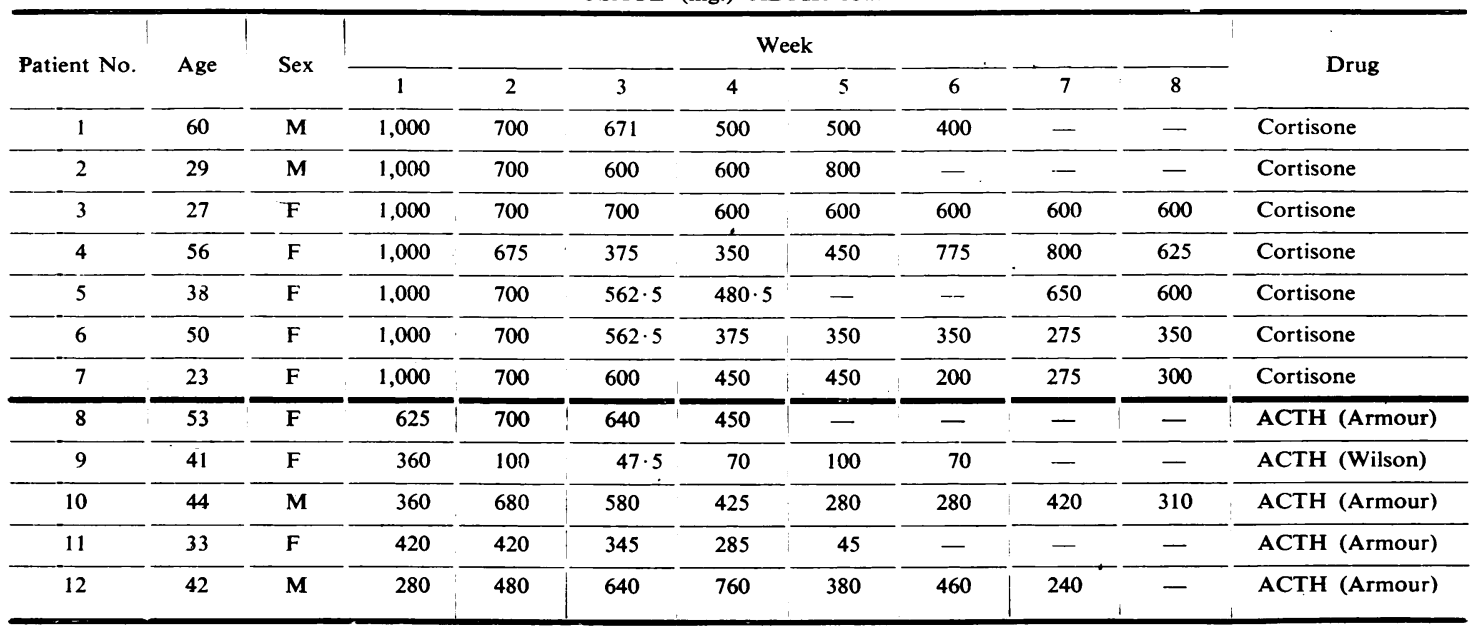




\section{Observations}

\section{Before the Start of Therapy}

Blood.-The initial red and white cell counts are shown in Tables II and III.

TABLE II

ABSOLUTE VALUES OF RED CELLS IN THIRTEEN CASES OF RHEUMATOID ARTHRITIS

\begin{tabular}{|c|c|c|c|c|}
\hline \multirow{2}{*}{ Cells } & \multicolumn{2}{|c|}{ Men (4) } & \multicolumn{2}{|c|}{ Women (9) } \\
\hline & Mean & Range & Mean & Range \\
\hline $\begin{array}{l}\text { Haemoglobin } \\
\text { (g. per } 100 \mathrm{ml} \text {. blood) }\end{array}$ & $11 \cdot 3$ & $10 \cdot 3-12 \cdot 3$ & $10 \cdot 8$ & $8 \cdot 2-12 \cdot 9$ \\
\hline $\begin{array}{l}\text { Red Cells } \\
\text { (millions per c.mm.) }\end{array}$ & $4 \cdot 3$ & $3 \cdot 8-4 \cdot 8$ & $4 \cdot 2$ & $3 \cdot 6-5 \cdot 1$ \\
\hline $\begin{array}{l}\text { Packed Cell Volume } \\
\text { (per } 100 \mathrm{ml} \text {.) }\end{array}$ & 36 & $31-39$ & 36 & $31-38$ \\
\hline $\begin{array}{c}\text { Mean Cell Volume } \\
\text { (cu. } \mu \text { ) } \\
\text {.. }\end{array}$ & 85 & $82-88$ & 85 & $72-98$ \\
\hline $\begin{array}{c}\text { Mean Cell } \\
\text { globin }(\gamma \gamma)\end{array}$ Haemo- & 26 & $25-27$ & 27 & $19-33$ \\
\hline $\begin{array}{l}\text { Mean Cell Haemo- } \\
\text { globin Concentration } \\
\text { (per cent.) } \ldots\end{array}$ & 31 & $29-33$ & 30 & $26-33$ \\
\hline $\begin{array}{l}\text { Reticulocytes } \\
\text { (per cent. of red cells) }\end{array}$ & 0.5 & $0 \cdot 2-1 \cdot 0$ & 0.6 & $0 \cdot 2-1 \cdot 8$ \\
\hline
\end{tabular}

TABLE III

LEUCOCYTE COUNT IN THIRTEEN CASES OF RHEUMATOID ARTHRITIS BEFORE THERAPY

\begin{tabular}{|c|c|c|c|c|}
\hline \multirow{2}{*}{\multicolumn{2}{|c|}{ Total Count (per c.mm.) }} & & Mean & Range \\
\hline & & & 7,400 & $4,700-9,700$ \\
\hline Neutrophils & $\left\{\begin{array}{l}\text { (per cent.) } \\
\text { (per c.mm.) }\end{array}\right.$ & $\begin{array}{l}\cdots \\
\cdots\end{array}$ & $\begin{array}{c}68 \\
4,510\end{array}$ & $\begin{array}{c}51 \cdot 5-80 \cdot 5 \\
766-6,120\end{array}$ \\
\hline Lymphocytes & $\left\{\begin{array}{l}\text { (per cent.) } \\
\text { (per c.mm.) }\end{array}\right.$ & 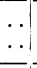 & $\begin{array}{c}22 \\
1,600\end{array}$ & $\begin{array}{l}9 \cdot 5-33 \cdot 5 \\
940-3,030 \\
\end{array}$ \\
\hline Monocytes & $\left\{\begin{array}{l}(\text { per cent.) } \\
(\text { per c.mm.) }\end{array}\right.$ & 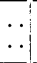 & $\begin{array}{l}6 \cdot 8 \\
410\end{array}$ & $\begin{array}{l}0-14 \\
0-1,162\end{array}$ \\
\hline Eosinophils & $\left\{\begin{array}{l}\text { (per cent.) } \\
(\text { per c.mm.) }\end{array}\right.$ & $\cdots$ & $\begin{array}{l}2 \cdot 7 \\
267\end{array}$ & $\begin{array}{c}0-10 \\
40-1,407\end{array}$ \\
\hline Miscellaneous & (per cent.) & .. & $\begin{array}{c}0 \cdot 3 \\
\text { plasma cells }\end{array}$ & $\begin{array}{c}0-2 \cdot 0 \\
\text { plasma cells }\end{array}$ \\
\hline
\end{tabular}

In six cases the platelet count ranged from 239,000 to 388,000 per c.mm. (mean 318,000 per c.mm.).

In ten cases the serum iron varied from 37-135 $\mu \mathrm{g}$. per $100 \mathrm{ml}$. serum (mean $72 \mu \mathrm{g}$.).

In thirteen cases the erythrocyte sedimentation rate (Westergren) varied from 21 to $110 \mathrm{~mm}$. in one hour (mean $57 \mathrm{~mm}$.).

Marrow.-The findings in twelve patients before and after therapy are shown in Table IV, in comparison with six normal myelograms. Almost pure blood was obtained from the sternum of a thirteenth patient. Sections from eleven marrows showed blood only (1), hypoplastic marrow (3), erythroi hypoplasia (1), normal marrow (4), and myeloị hyperplasia (2).

TABLE IV

MEAN FIGURES OF MARROW COUNTS (CELLS PER CENT.)

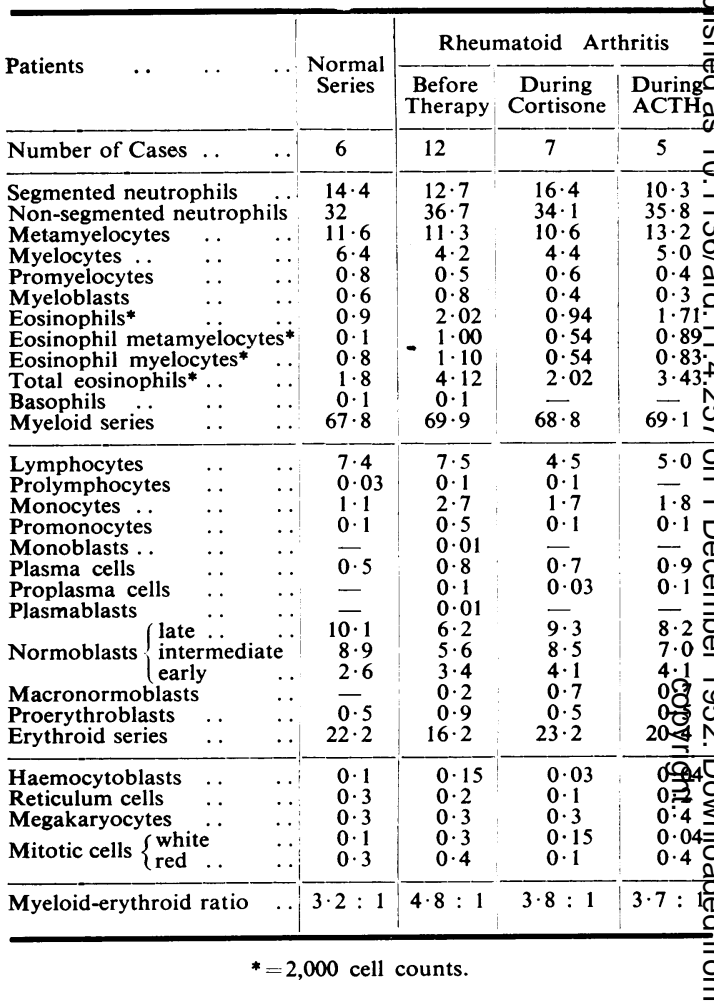

Gastric Juice.-Analysis in ten cases showed tha跑 eight patients had no free acid in the fasting specimed and two had none in any specimen.

\section{During and After Therapy}

(a) Changes in Red Cells.-Seven cases receive cortisone and five received ACTH. The changes in the red cells at 3 weeks are summarized i Table $\mathrm{V}$ and Student's " $t$ " test applied. The absolute values calculated from these figures showed no significant change.

In the cases receiving cortisone the reticulocyte showed a small non-significant rise during the early weeks of therapy.

(b) Changes in Blood Leucocytes.-Six cases treated with cortisone showed a significant leuco $=$ cytosis due to a significant neutrophilia after 3 weeks 
TABLE $\mathbf{V}$

RED CELL CHANGES AT 3 WEEKS DURING HORMONE THERAPY

\begin{tabular}{|c|c|c|c|c|c|c|}
\hline Drug & & Estimation & $\begin{array}{c}\text { Number } \\
\text { of } \\
\text { Cases }\end{array}$ & Mean change at 3 weeks & $\begin{array}{c}\text { Standard } \\
\text { Deviation } \\
\text { of the Mean }\end{array}$ & $\begin{array}{c}\text { Level of } \\
\text { Significance } \\
\text { (Student's “ } t \text { ") }\end{array}$ \\
\hline \multirow{3}{*}{ Cortisone } & \multirow{3}{*}{$\cdots$} & Haemoglobin & 6 & $+1 \cdot 13$ g. per cent. & $2 \cdot 76$ & 0.05 . Very slight significance \\
\hline & & Red cell count & 6 & +0.6 (millions per c.mm.) & $2 \cdot 34$ & $0 \cdot 1$. Insignificant \\
\hline & & Packed cell volume & 6 & $+2 \cdot 67$ per cent. & $3 \cdot 76$ & 0.02. Slight significance \\
\hline \multirow{3}{*}{ АCTH } & & Haemoglobin & 5 & +0.98 g. per cent. & $2 \cdot 18$ & $0 \cdot 1$ Insignificant \\
\hline & $\cdots$ & Red cell count & 5 & +0.46 (millions per c.mm.) & $2 \cdot 19$ & $0 \cdot 1$. Insignificant \\
\hline & & Packed cell volume & 5 & $+4 \cdot 8$ per cent. & $2 \cdot 96$ & 0.05 . Very slight significance \\
\hline
\end{tabular}

therapy. The lymphocytes, monocytes, and eosinophils showed no significant change (Table VI) at 3 weeks. Three cases showed no change in blood eosinophils, one showed an immediate, maintained fall, two showed an immediate fall and subsequent rise, one showed no immediate fall but a subsequent rise. "Falls" and "rises" imply at least a halving or a doubling of the initial count.

\section{TABLE VI}

CHANGES IN LEUCOCYTES AT 3 WEEKS DURING CORTISONE THERAPY

\begin{tabular}{l|c|c|c|c|c}
\hline \multicolumn{1}{c|}{ Cells } & $\begin{array}{c}\text { Number } \\
\text { of } \\
\text { Cases }\end{array}$ & $\begin{array}{c}\text { Mean } \\
\text { Change } \\
\text { (per } \\
\text { c.mm.) }\end{array}$ & $\begin{array}{c}\text { Standard } \\
\text { Deviation } \\
\text { of the } \\
\text { Mean }\end{array}$ & $\begin{array}{c}\text { Level of } \\
\text { Significance , } \\
\text { (Student's “ } t \text { ”) }\end{array}$ \\
\hline Total Leucocytes & 6 & $+3,192$ & $5 \cdot 03$ & 0.01 Significant \\
\hline Neutrophils & $\ldots$ & 6 & $+2,597$ & $5 \cdot 70$ & 0.01 Significant \\
\hline Lymphocytes & $\cdots$ & 6 & +601 & $1 \cdot 85$ & Insignificant \\
\hline Monocytes & $\cdots$ & 6 & +59 & 0.56 & Insignificant \\
\hline Eosinophils &. & 6 & -98 & 0.63 & Insignificant \\
\hline
\end{tabular}

Leucocyte counts in the ACTH series were too incomplete for analysis, but two cases showed no change in the eosinophils and three showed an immediate fall followed by an "escape" to the original level whilst therapy continued.

(c) Changes in Platelets.-Not followed.

(d) Changes in Serum Iron.-Followed in seven cases.

Three men showed a mean of $84 \mu \mathrm{g}$. per cent. before and $86 \mu \mathrm{g}$. per cent. during hormone therapy (normal figures for these ages $106 \mu \mathrm{g}$. per cent.Pirrie, 1952).

Four women showed a rise in the mean serum iron level from $48 \mu \mathrm{g}$. before to $74 \mu \mathrm{g}$. during therapy (normal figure for these ages $99 \mu \mathrm{g}$.). (e) Changes in E.S.R.-All cases treated with cortisone showed a decrease: in one case to 35 $\mathrm{mm} . / 1 \mathrm{hr}$, in three cases to between 13 and $20 \mathrm{~mm}$. and in three cases to below $13 \mathrm{~mm}$. From 2 to 6 weeks were necessary for the maximum fall. Of five cases followed after therapy, two remained below their initial figure, two became raised above it, and one almost equalled it.

All cases treated with ACTH showed a decrease: in one case to $24 \mathrm{~mm}$., in one case to $20 \mathrm{~mm}$., and in three cases to below $13 \mathrm{~mm}$. in 1 hour.

Of four cases followed after therapy, two remained below their initial figure and two rose above it. ।

(f) Changes in Bone Marrow.-These were studied by means of films and sections made from aspirated material, but no total counts were made because of their reported unreliability.

In seven cases treated with cortisone the myeloid series showed no significant change (Table IV, opposite, and Table VII, overleaf).

Considered separately, one patient (Case 6) showed a fall in the percentage figures due to a marked erythroid hyperplasia, and another (Case 2) showed a rise which was probably absolute as well as relative, because the percentage figures showed a "shift to the right" and the marrow section showed an increase in myeloid cells.

The total eosinophils showed a fall from $4 \cdot 12$ per cent. to 2.02 per cent. (mean figures), but the change is not significant.

The erythroid series showed no significant change in the series as a whole. Considered separately, two patients (Cases 4 and 6) showed an impressive increase $(18 \cdot 2$ to $37 \cdot 2$ per cent. and 12.6 to $37 \cdot 8$ per cent., respectively).

The lymphocytes showed a fall from $7 \cdot 5$ to $4 \cdot 5$ per cent. (mean figures) which is significant at the 0.05 level. 
TABI.E VII

CHANGES IN BONE MARROW DURING HORMONE THERAPY

\begin{tabular}{|c|c|c|c|c|c|}
\hline Drug & Cells & $\begin{array}{c}\text { Number } \\
\text { of } \\
\text { Cases }\end{array}$ & $\begin{array}{c}\text { Mean Change after Therapy } \\
\text { (per cent.) }\end{array}$ & $\begin{array}{c}\text { Standard } \\
\text { Deviation } \\
\text { of the Mean } \\
\end{array}$ & $\begin{array}{c}\text { Significance } \\
\text { of the Change } \\
\text { (Student's " } t " \text { ) }\end{array}$ \\
\hline \multirow{4}{*}{ Cortisone } & Myeloid cells & 7 & -0.97 & $3 \cdot 42$ & Insignificant \\
\hline & Tota! eosinophils & 7 & $--1 \cdot 91$ & $1 \cdot 21$ & Insignificant \\
\hline & Lymphocytes & 7 & $-3 \cdot 00$ & $-1 \cdot 07$ & $0 \cdot 05$. Slight significance \\
\hline & Erythroid cells & 7 & $+5 \cdot 37$ & $4 \cdot 35$ & Insignificant \\
\hline \multirow{4}{*}{ ACTH } & Myeloid cells & 5 & $-0 \cdot 36$ & $5 \cdot 77$ & Insignificant \\
\hline & Total eosinophils & 5 & -0.94 & $1 \cdot 71$ & Insignificant \\
\hline & Lymphocytes & 5 & $-2 \cdot 72$ & $2 \cdot 1 \overline{5}$ & Insignificant \\
\hline & Erythroid cells & 5 & $+4 \cdot 80$ & $4 \cdot 00$ & Insignificant \\
\hline \multirow{4}{*}{ Combined Series } & Myeloid cells & 12 & $-0 \cdot 72$ & $3 \cdot 15$ & Insignificant \\
\hline & Total eosinophils & 12 & $-1 \cdot 50$ & $3 \cdot 12$ & Insignificant \\
\hline & Lymphocytes & 12 & $-2 \cdot 88$ & $0 \cdot 83$ & Significant at 0.02 level \\
\hline & Erythroid cells & 12 & $+5 \cdot 13$ & $1 \cdot 04$ & Insignificant \\
\hline
\end{tabular}

In five cases treated with ACTH no significant change was found in the myeloid series, total eosinophils, lymphocytes, or erythroid series (Tables IV and VII).

One patient (Case 10) showed a myeloid hyperplasia. The total eosinophils fell from $4 \cdot 12$ to 3.43 per cent. (mean figures).

The lymphocytes fell from $7 \cdot 5$ to $5 \cdot 0$ per cent. (mean figures) and three patients (Cases 8,9 , and 12), showed an erythroid hyperplasia $(15 \cdot 6$ to $28 \cdot 4$ per cent., $12 \cdot 8$ to $21 \cdot 2$ per cent., and $8 \cdot 2$ to $21 \cdot 6$ per cent. respectively) which was due mainly to an increase in the more mature normoblasts. The percentage of macronormoblasts increased slightly. The myeloid : erythroid ratio fell from $4 \cdot 8: 1$ to $3 \cdot 8: 1$ and $3 \cdot 7: 1$ during cortisone and ACTH therapy respectively, a shift in the direction of normality $(3 \cdot 2: 1)$.

If the cortisone and ACTH series are considered together (Table VII) the fall in the lymphocytes becomes more significant (at the $0 \cdot 2$ level) but the other changes remain insignificant.

The monocytes and their precursors showed a fall towards normal from $3 \cdot 2$ per cent. to $1 \cdot 8$ per cent. during cortisone therapy and to 1.9 per cent. during ACTH therapy (mean figures). The plasma cells showed no change.

( $g$ ) Changes in Gastric Juice.--Not followed.

\section{Discussion and Analysis}

The patients were selected for their willingness to co-operate and for severe polyarthritis. Anaemia was ignored in their selection. Thus the degree of anaemia found is not typical of rheumatoid arthritio in general, but only of cases selected for moderate duration and severity of arthritis. All the patients showed considerable improvement clinically i enough hormone was given, and it was endeavoured. to keep the response constant from patient to patien by variation of the dose rather than to give ${ }^{N}$ standard course of therapy and note the varia in the clinical response.

It is probably for this reason that the haemato logical variations do not appear to correspond a closely with clinical improvement as was noted b9 Finch and others (1951) in their hormone treate $\vec{\Phi}$ series, or by Nilsson (1948) in his iron treated cases?

I. Cases before Therapy.-As was to be expecte $\frac{\text { P. }}{\text { P. }}$ from previous work, all the patients but one (Case 79 showed some degree of anaemia, the women showing lower values than the men. The anaemia waş normocytic and slightly hypochromic, the reticulon cytes and serum iron low, and erythropoiesis in the marrow normal or depressed, the most mature normoblasts being the most affected.

The blood neutrophils, lymphocytes, monocytes? and plasma cells were normal. The eosinophils were normal in all but one case. In the marrowo leucopoiesis varied from poor to active. N@ marked "shift to the left" was seen. The lymphoN cytes were normal. Plasmacytes were slightly increased, but the high figures of Hayhoe and Smith (1951), and of earlier continental workerse were not found, nor was there any increase iron reticulum cells or megakaryocytes. There was slight monocytosis $(3 \cdot 21$ per cent. monocytes anff 
precursors) and an eosinophilia ( $4 \cdot 12$ per cent.). Because of the method of selection all patients had a raised erythrocyte sedimentation rate.

II. Effects of Therapy.-During therapy the haemoglobin, red cell count, and packed cell volume rose in six out of seven cases treated with cortisone. At 3 weeks the mean rise of the seven cases was just significant, but about half the gain had been lost by the 8th week. Five cases treated with ACTH showed similar changes at 3 weeks, but the smaller number of cases resulted in a lower degree of significance. It is probable that at least half the gain at 3 weeks was due to alterations in the plasma volume (see Robinson, 1943; Finch and others, 1951; Copeman and others, 1952). By 8 weeks doses of the hormone were in most cases small or had ceased and the apparent gain in the red cell mass at this time was probably a true one. The reticulocytes showed only a small gain and it seems probable that the large quantaties of blood removed by some investigators may have contributed to the height of the reported subsequent reticulocyte crisis.

Study of the erythroid series in the sternal marrow showed that in five of the twelve patients there was a well-marked erythropoietic response, and it is interesting that the mean initial haemoglobin of these 5 patients (four women and one man) was $1 \mathrm{~g}$. per $100 \mathrm{ml}$. below the mean initial haemoglobin of the group. The mean haemoglobin of Cases 4, 6, 8 , and 9 was $9.8 \mathrm{~g}$. (mean for women, $10 \cdot 8 \mathrm{~g}$.). The haemoglobin of Case 12 was $10 \cdot 3 \mathrm{~g}$. (mean for men, $11 \cdot 3$ g.).

No correlation was noted between erythropoiesis and clinical response, probably because the dosage was varied widely to obtain a fairly standard clinical improvement, so that the most anaemic patients would need to respond most vigorously.

A moderate degree of anaemia has been shown to follow several hormone deficiencies which usually responded to treatment with the appropriate hormone (Gordon and Charipper, 1947; Daughaday and others, 1948). Similarly, in these cases of rheumatoid arthritis, the most anaemic patients reacted the most vigorously to cortisone and ACTH. It is probable that the hormones affected the disease processes which had inhibited normal erythropoiesis, so setting the marrow free to respond appropriately to the state of anaemia.

The similarity of the anaemia in infection and in rheumatoid arthritis has been pointed out by Kuhns and others (1950). Their six cases of polyarthritis showed a mean serum iron of $38 \mu \mathrm{g}$. (mean) and the response to intravenous iron was poor. Four women in our series showed a well-marked rise, from $48 \mu \mathrm{g}$. (mean) to $74 \mu \mathrm{g}$. (mean), on ACTH or cortisone, but did not attain the normal mean of $99 \mu \mathrm{g}$. Nor did three men in our series reach normality, which may be explained by the observation of Cartwright and others (1951) that ACTH and cortisone depress the serum iron level in dogs.

The changes seen in the leucocytes in the peripheral blood agreed closely with the observations of Finch and others (1951). The leucocytosis due to a neutrophilia was seen and was significant. No other change was significant, but in three cases there was an immediate eosinopenia and in three cases the initial eosinophil count was later more than doubled. Three of the five cases treated with ACTH showed an immediate eosinopenia with an "escape" to the original level in all.

The changes in the marrow are of considerable interest, though the smallness of the series limits their scientific value. The myeloid series as a whole showed no significant change after therapy, nor was there any "shift" to the left or right in the mean figures. Two cases showed increased leucopoiesis during therapy. Only three marrows were examined within 48 hours of starting therapy, but none showed the accumulation of mature myeloid cells found in mice by Antopol and others (1951).

The mean marrow eosinophil percentage showed no significant change, in spite of peripheral eosinopenia, in our combined ACTH and cortisone series, thus agreeing with Rosenthal and others (1950), Finch and others (1951), and Best and Samter (1951). The cortisone and ACTH series considered separately showed a change in the mean marrow eosinophils from $4 \cdot 12$ per cent. to 2.02 and 3.43 per cent. respectively.

Both cortisone and ACTH caused a similar and considerable fall in the marrow lymphocytes, which is significant at the 0.02 level for the combined series. This change has not been generally remarked in the human cases, possibly because the lymphocytes of the myelogram are usually considered to come from the blood. The work of Veeneklaas (1938), Blitstein (1945), Yoffey and others (1944-50) strongly suggests that the lymphocyte is also a true marrow cell.

The marrow monocytes fell to $1 \cdot 8$ per cent. during cortisone and to 1.9 per cent. during ACTH therapy; this phenomenon also has not been previously described:

No change was observed in the plasma cells, reticulum cells, or megakaryocytes, nor was there any correlation between plasmacytosis and the E.S.R. (Šitaz and Kresánek, 1949).

The E.S.R. fell during therapy in all cases, especially between the 2nd and 6th weeks of therapy; 
in half of the cases it fell to below $13 \mathrm{~mm}$./ $1 \mathrm{hr}$. The degree of change indicated the degree of clinical improvement, but interpretation is obviously more difficult since Shock (1951) showed that ACTH reduces the E.S.R. in normal people.

\section{Summary}

(1) The blood, marrow, and gastric juice of thirteen cases of severe rheumatoid arthritis of moderate duration have been examined.

(2) Five cases received ACTH and seven received cortisone in sufficient dosage to obtain and maintain a considerable degree of clinical improvement.

(3) During the period of improvement serial examinations of the blood and marrow were made. The haemoglobin, red cell count, and packed cell volume rose in ten of the twelve cases to a degree significant at a low level, but half the gain had been lost by the 5th to 8th week, presumably on account of changes in the plasma volume caused by the therapy. The reticulocytes showed a small increase. Five of the twelve patients showed a well-marked erythroid response, which did not correspond with increased clinical response, but did correspond with the most severe degrees of anaemia. The response appeared to be due to release from the inhibiting effects of disease rather than a true "stimulation" of the marrow.

(4) Four women showed rises in the serum iron during therapy. Three men who started at a higher level showed no change. None achieved the normal level.

(5) During cortisone therapy there was a significant leucocytosis due to a significant neutrophilia. Changes in the other leucocytes were not significant, but about half the cases showed an immediate eosinopenia or a later eosinophilia. Three out of five cases treated with ACTH showed an immediate eosinopenia with subsequent " escape". In the marrow, the myeloid series showed no significant change or shift, apart from increased leucopoiesis in two cases. The mean marrow eosinophils fell after cortisone and ACTH therapy, from $4 \cdot 12$ per cent. to 2.02 and 3.43 per cent. respectively. The change is not significant.

(6) ACTH and cortisone caused a significant fall in the marrow lymphocytes. The monocytes also fell, but did not reach significance.

(7) No change during therapy was noted in the plasma cells, reticulum cells, or megakaryocytes.

(8) The erythrocyte sedimentation rate fell in all cases during therapy, in half of them to less than $13 \mathrm{~mm} . / 1 \mathrm{hr}$ (Westergren).

Many people have helped to make this investigation possible, but the authors are particularly grateful to Dr. A. Gordon Signy, Director of the Group $\frac{D^{2}}{(1}$ Laboratory, St. Mary Abbots Hospital, to Drs. F. J. Bach, W. S. C. Copeman, Philip Ellman, B. Gottlieb, and Oswald Savage, for access to patients in their care, $\frac{}{\omega}$. to the patients themselves, to Dr. J. H. H. Glyn, to Dr. Huggie for marrow films and data of two patients $\overrightarrow{\vec{\rho}}$ investigated at the West London Hospital, and to Miss $\frac{7}{0}$ M. A. Crosskey for the statistical analysis. One of us $\frac{\mathrm{C}}{0}$ (J.O.P.E.) must thank the Regius Professor of Physic in $\frac{\bar{\omega}}{\omega}$ the University of Cambridge for permission to use $\frac{\widehat{\sigma}}{\vec{\sigma}}$ material previously presented in a thesis for the degree $\unrhd$ of M.D.

\section{REFERENCES}

Antopol, W., Glaubach, S., and Quittner, H. (1951). Rheumatism, 7 (no. 1), p. 187 .

Best, W. R., and Samter, M. (1951). Blood, 6, 61.

Blitstein, I. (1945). C.R. Soc. Biol., Paris, 139, 331

Cartwright, G. E. Gubler, C. J Hamilton, L. D. Fellows, N. M and Wintrobe, M. M. (1951). "Proceedings of the Second Clinical ACTH Conference, Chicago," vol. 1, p. 405. Churchill, "

London.
Copeman, W. S. C., Savage, O., Bishop, P. M. F., Dodds, E. C., Kellie, A. E., Stewart, J. W., Glyn, J. H. H., Henly, A. A., and A Tweed, J. M. (1952). Brit. med. J., 1, 397.

Dacie, J. V. (1950). " Practical Haematology." Churchill, London. G Daughaday, W. H., Williams, R. H., and Daland, G. A. (1948).

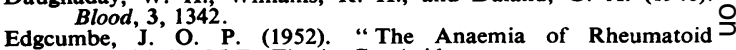
Arthritis." M.D. Thesis, Cambridge.

Finch, S. C., Crockett, C. L., Ross, J. F., and Bayles, T. B. (1951). Blood, 6, 1034.

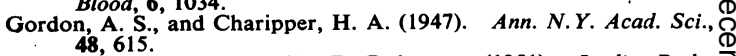

Hayhoe, F. G. J., and Smith, D. Robertson (1951). J. clin. Path.,

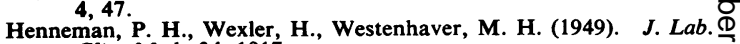
Clin. Med., 34, 1017.

Kuhns, W. J., Gubler, W. J., Cartwright, G. E., and Wintrobe, M. (1950). J. clin. Invest., 29, 1505.

Nilsson, F. (1948). Acta med. scand., Suppl. 210.

Pirrie, R. (1952). J. clin. Path., 5, 10 . Robinson, G. L. (1943). Annals of the Rheumatic Diseases, 3, 2 .

Rosenthal, R. L., Wald, N., Yager, A., and Litwins, J. (1950). 'Proc. Soc. exp. Biol. N.Y., 75, 740.

Shock, N. (1951). "Proceedings of the Second Clinical ACTHO Conference, Chicago,"' vol. 2, p. 568. Churchill, London.

Šitaz, S., and Kresánek, E. (1949). Čas. Lék. čes., 88, 1444.

Sitaz, S., and Kresanek, E. (1949). Cas. Lek. ces., 88, 1444. 315 . ฉ

Veeneklaas, G. M. H. (1938). "Sternumpunktie bij Kinderen." Jens, Utrecht. Quoted by Blitstein (1945).

Westergren, A. (1921). Acta med. scand., 54, 247.

White, J. C., Baker, J. R., and Griffin, J. G. (1946). J. Path. Bact., $58,155$.

Yoffey, J. M. (1950). Biol. Rev., 25, 314.

(1949). Unpublished observations cited by Yoffey (1950).

—, and Parnell, J. (1944). J. Anat., Lond., 78, 109.

Effets de l'ACTH et de la cortisone sur l'anémie de l'arthrite rhumatismale

RÉSUMÉ

(1) On a examiné le sang, la moelle osseuse, et le suc윽 gastrique dans treize cas d'arthrite rhumatismale grave et d'ancienneté modérée.

(2) Cinq cas ont reçu de l'ACTH et sept autres de la cortisone en doses suffisantes pour obtenir et maintenir une amélioration clinique considérable.

(3) Au cours de la période d'amélioration on $a_{\odot}^{N}$ procédé à une série d'examens du sang et de la moelle. NW Dans dix cas sur douze l'hémoglobine, le nombre des $\omega$ globules rouges, et le volume globulaire ont accusé une augmentation signifiante, sans toutefois dépasser uno niveau bas. La moitié de ce gain fut reperdue entre la 5 me et la 8 me semaine, probablement à conséquence desê altérations du volume plasmatique provoquées par le traitement. Il $y$ a eu une légère augmentation du뭉 
chiffre des réticulocytes. Cinq malades sur douze ont manifesté une réponse érythroïde bien marquée correspondante à la grande sévérité de l'anémie et non pas à l'intensité de l'amélioration clinique. Cette réponse a paru résulter de la suppression des effets inhibiteurs de la maladie plutôt que d'une vraie "stimulation" de la moelle.

(4) Chez 4 femmes le chiffre du fer sérique a accusé une augmentation, tandis que chez 3 hommes, chez qui ce chiffre avait été plus élevé au commencement, on n'a observé aucune modification. Personne n'a atteint un taux normal.

(5) Pendant la thérapie à la cortisone il y a eu une leucocytose signifiante due à une neutrophilie signifiante. Les autres déviations leucocytaires n'ont pas été signifiantes, mais dans prés de la moitié des cas on a observé une éosinopénie, suivie d'un "échappement". Dans la moelle, la lignée myéloïde n'a accusé aucune modification ni déviation signifiante, à l'exception de deux cas de leucopoyèse augmentée. Les éosinophiles de la moelle sont tombés après le traitement par la cortisone et l'ACTH de $4,12 \%$ à $2,02 \%$ et $3,43 \%$ respectivement. Cette altération n'est pas signifiante.

(6) L'ACTH et la cortisone ont provoqué une chute signifiante des lymphocytes myéloïdes. Il y a eu aussi une diminution des monocytes, pas assez prononcée pour être signifiante.

(7) Au cours du traitement on n'a pas observé d'altérations en ce qui concerne les plasmocytes, les réticulocytes, et les mégacaryocytes.

(8) Il a eu une diminution de la vitesse de sédimentation dans tous les cas traités; dans la moitié de ces cas elle a été en dessous de $13 \mathrm{~mm}$. en 1-re heure (Westergren).

\section{Efectos de la ACTH y de la cortisona sobre la anemia de la artritis reumatoide \\ Sumario}

(1) Se ha examinado là sangre, la médula ósea, y el jugo gástrico en trece casos de artritis reumatoide grave y de duración moderada.

(2) Cinco casos recibieron ACTH y siete cortisona en dosis suficientes para obtener y mantener una mejoría clínica considerable.

(3) Durante el período de mejoría se ha procedido a series de investigaciones de la sangre y de la médula. En diez de los doce casos las cifras de la hemoglobina, de los eritrocitos, y del volumen corpuscular, aunque siempre bajas, aumentaron de manera estadísticamente significante. La mitad de esta ganancia fué perdida entre la quinta y la octava semana, probablemente a consecuencia de las alteraciones del volumen plasmático causadas por el tratamiento. El número de los reticulocitos estuvo algo aumentado. Cinco de los doce enfermos manifestaron una reacción eritroide bien acentuada que no correspondía a la intensidad de la mejoría clínica sino a la gran severidad de la anemia. Esta reacción pareció resultar más bien de la supresión de los efectos inhibidores de la enfermedad que de la auténtica "estimulación" medular.

(4) En 4 mujeres las cifras del hierro en el suero aumentaron; en 3 hombres estas cifras, más altas al principio, quedaron sin cambiar. En ninguno el hierro alcanzó valores normales.

(5) Durante el tratamiento con la cortisona se observó una leucocitosis significante debida a una neutrofilia significante. Otras desviaciones leucocitarias no tuvieron importancia, pero en cerca de la mitad de los casos hubo una eosinopenia, seguida de "fuga". En la médula, la serie medular no reveló alteraciones o desviaciones significantes, a excepción de la leucopoyesis aumentada en dos casos. Los valores de los eosinófilos bajaron después del tratamiento con cortisona y con ACTH de $4,12 \%$ a $2,02 \%$ y $3,43 \%$ respectivamente. Estas alteraciones no tienen significancia estadística.

(6) La ACTH y la cortisona motivaron una baja significante de las cifras de los linfocitos medulares. Las cifras de los monocitos también bajaron, sin alcanzar una diferencia significante.

(7) Durante el tratamiento no se observó alteraciones en los plasmocitos, reticulocitos, o megacariocitos.

(8) La velocidad de sedimentación durante el tratamiento bajó en todos los casos, descendiendo debajo de $13 \mathrm{~mm}$./1-ra hora (Westergren) en la mitad de ellos. 